DOI: 10.12731/2658-6649-2019-11-5-2-68-72

УДК 57.085.23

\title{
БИОЛОГИЧЕСКИЕ ЭФФЕКТЫ КОМПОНЕНТОВ «THIRD-HAND SMOKE» В КУЛЬTУРЕ ЭРИТРОЦИТОВ
}

\section{Максимова O.P.}

В работе изучали биологическую активность продуктов THS в кратковременной культуре эритроцитов in vitro. Было показано, что продукты THS вызывали дозо-зависимое снижение жизнеспособности эритроцитов, которое сопровождалось снижением сорбиионной емкости клеток, сорбционной емкости гликокаликса и осмотической резистентности эритроцитов. Эффекты продуктов THS в культуре эритроцитов некурящих и некурящих доноров существенно различались. Предполагается, что выявленная вариабельность эффектов продуктов THS связана с компенсаторно-адаптивными перестройками мембран эритроцитов in vivo у курящих доноров.

Ключевые слова: эритроциты; курение; дым «в третьи руки».

\section{THE BIOLOGICAL EFFECTS OF THE COMPONENTS OF THE "THIRD-HAND SMOKE" IN THE CULTURE OF ERYTHROCYTES}

\section{Maksimova O.R.}

We studied the biological activity of THS products in a short-term culture of erythrocytes in vitro. It was shown that THS products caused a dose-dependent decrease in the viability of red blood cells, which was accompanied by a decrease in the sorption capacity of cells, the sorption capacity of glycocalyx and the osmotic resistance of red blood cells. The effects of THS products on non-smoking and non-smoking donors in erythrocyte culture differed significantly. It is assumed that the revealed variability of the effects of THS products is associated with compensatory-adaptive rearrangements of erythrocyte membranes in vivo in smoking donors.

Keywords: RBC; THS; smoking. 


\section{Введение}

Согласно определению ВО3, продукты THS представляют собой остаточное загрязнение продуктами табачного дыма, которые оседают на частицах пыли, различных поверхностях в помещениях. Эти продукты могут подвергаться химическим модификациям с участием кислорода и превращаться в более токсичные формы [1]. В продуктах THS выявлено наличие наноразмерных частиц, что может определять их высокую биологическую активность [2, с. 348].

Молекулярно-клеточные механизмы биологической активности продуктов THS изучены недостаточно. Особая актуальность проблемы состоит еще в том, что воздействию продуктов THS подвергаются люди, не имеющие привычки курения. И биологические эффекты продуктов THS у курильщиков со стажем и у некурящих людей могут существенно различаться.

Целью данной работы являлось изучение влияния продуктов THS на структурно-функциональную стабильность мембран эритроцитов в культуре in vitro у некурящих доноров (НКД) и курящих доноров (КД).

\section{Материалы и методы исследования}

Выборка доноров (женщины, возраст 22 года) была сформирована на основе анкетирования. Эритроциты выделяли из капиллярной крови (у КД капиллярную кровь получали до и через 10 мин после выкуривания сигареты) и инкубировали на среде с $0,1 \mathrm{M}$ PBS и 5мМ глюкозой с различными концентрациями продуктов THS (10, 50 и 100 у.е.) в течение 2 ч при $\mathrm{T}=37^{\circ} \mathrm{C}$. После завершения инкубации определяли жизнеспособность клеток с помощью МТТ-теста [3], осмотическую резистентность (ОРЭ) [4], сорбционную емкость эритроцитов (СЕЭ) и сорбционную емкость гликокаликса (СЕГ) [5].

\section{Результаты и обсуждение}

В условиях кратковременного культивирования in vitro продукты THS снижали жизнеспособность клеток НКД в 2.4 раза, по сравнению с контролем. В группе КД дозо-зависимое снижение жизнеспособности наблюдалось только для варианта до выкуривания сигареты (рис. 1А). Снижение жизнеспособности эритроцитов под влиянием THS сопровождалось структурно-функциональными перестройками клеточных мембран. Продукты THS в концентрации 100 у.е. уменьшали СЕЭ у НКД в 2.5 раза, а у КД до выкуривания сигареты - в 2 раза, по сравнению с контролем (рис. 
1В). СЕЭ зависит от активности проникновения витального красителя. Вероятно, снижение СЕЭ под влиянием продуктов THS обусловлено снижением активности мембранного транспорта.

Продукты THS вызывали изменения СЕГ только в группе КД до выкуривания сигареты: для концентрации 100 у.е. отмечалось уменьшение сорбционной емкости гликокаликса в 3 раза, по сравнению с контролем (рис. 1Г). Можно полагать, что у КД in vivo реализуются перестройки гликокаликса, в результате которых он активно связывает продукты THS, а число сайтов связывания молекул красителя уменьшается. Перестройки мембранного гликокаликса in vivo у КД могут нарушать взаимодействие эритроцитов с другими типами клеток в сосудистом русле.
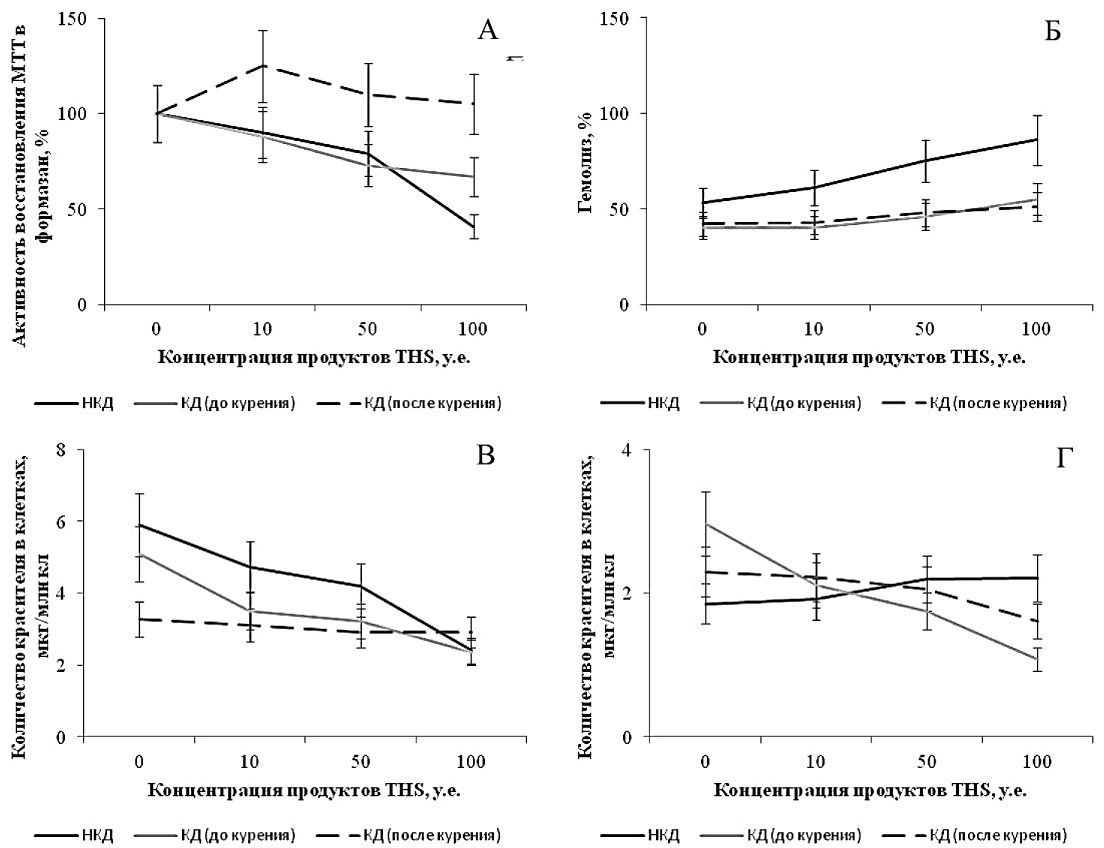

Рис. 1. Жизнеспособность (А), активность гемолиза (Б), СЕЭ (В) и СЕГ (Г) эритроцитов в условиях кратковременного культивирования на средах с различной концентрацией продуктов THS. НКД - некурящие доноры, КД - курящие доноры

У НКД продукты THS в концентрации 100 у.е. увеличивали активность гемолиза в 1,6 раза, по сравнению с контролем (рис. 1Б). Можно предположить, что продукты THS снижают структурную стабильность мембран. 
Возможной причиной снижения структурной стабильности мембран может быть индуцированный THS окислительный стресс и накопление в мембране окисленных форм липидов. У КД продукты THS в исследованных концентрациях не вызывали достоверных изменений ОРЭ. Устойчивость эритроцитов КД к гемолизу может быть обусловлена увеличением содержания холестерина в мембране, что повышает ее «жесткость» и устойчивость в гипотонических растворах. Однако в условиях in vivo повышенная жесткость мембран эритроцитов может неблагоприятно влиять на их транспортную функцию и уменьшать продолжительность циркуляции в сосудистом русле.

Полученные результаты позволяют говорить о цитотоксичности продуктов THS в кратковременной культуре эритроцитов in vitro. Причем, цитотоксичность продуктов THS в группе КД была значительно ниже, чем в группе НКД. Эти различия могут быть связаны с компенсаторно-адаптивными перестройками клеточных мембран эритроцитов in vivo у КД.

\section{Список литературы}

1. The World Health Organization: [Электронный ресурс] / Режим доступа: http://www.who.int/features/factfiles/tobacco/en/index.html

2. Becquemin, M. H. Third-hand smoking: indoor measurements of concentration and sizes of cigarette smoke particles after resuspension/ M. H. Becquemin, J.F. Bertholon et al. // Tobacco control. 2010. V. 19. №. 4, pp. 347-348.

3. MTT assay protocol: [Электронный ресурc] / URL: http://www.abcam.com/ kits/mtt-assay-protocol

4. Способ определения осмотической резистентности эритроцитов: патент 2328741 Рос. Федерация № 2007116258/15, заявлен 07.12.2009; опубликован 27.05.2011.

5. Способ оценки сорбционной емкости клетки: патент 2328741 Рос. Федерация № 2007116258/15, заявлен 07.12.2009; опубликован 27.05.2011.

\section{References}

1. The World Health Organization: [online] / URL: http://www.who.int/features/ factfiles/tobacco/en/index.html

2. Becquemin, M. H. Third-hand smoking: indoor measurements of concentration and sizes of cigarette smoke particles after resuspension/ M. H. Becquemin, J.F. Bertholon et al. // Tobacco control. 2010. V. 19. №. 4, pp. 347-348.

3. MTT assay protocol: [online] / URL: http://www.abcam.com/kits/mtt-assay-protocol 
4. Method for determining the osmotic resistance of red blood cells: patent 2328741 Russian Federation № 2007116258/15, declared 07.12.2009; published 27.05.2011.

5. A method of estimating the sorption capacity of cell: patent 2492486 Russian Federation № 2012125089/15, declared 15.06.2012; published 10.09.2013.

\section{ДАННЫЕ ОБ АВТОРЕ}

Максимова Ольга Руслановна, магистр 1-го года обучения

Федеральное государственное автономное образовательное учреждение высшего образования «Сибирский федеральный универcumem»

Свободный проспект, 79, г. Красноярск, 660041, Российская Федерачия

olga.maksimova.96@yandex.ru

\section{DATA ABOUT THE AUTHOR}

Maksimova Olga Ruslanovna, master of 1st year

Siberian Federal University

79, Svobodny prospect, Krasnoyarsk, 660041, Russian Federation

olga.maksimova.96@yandex.ru 